\title{
Differentiation and Detection of Sugar Beet Fungal Pathogens Using PCR Amplification of Actin Coding Sequences and the ITS Region of the rRNA Gene
}

\author{
John J. Weiland and Jamie L. Sundsbak, Sugarbeet and Potato Research Unit Northern Crop Science Laboratory, \\ United States Department of Agriculture-Agricultural Research Service, Fargo, ND 58105-5677
}

\begin{abstract}
Weiland, J. J., and Sundsbak, J. L. 2000. Differentiation and detection of sugar beet fungal pathogens using PCR amplification of actin coding sequences and the ITS region of the rRNA gene. Plant Dis. 84:475-482.

The DNA sequences of the actin genes of several fungi were compared and highly conserved regions in the coding sequence were identified. Deoxyoligonucleotide primers were synthesized based on conserved sequence blocks in the $5^{\prime}$ and $3^{\prime}$ ends of the open reading frame encoding the actin protein. In addition, primers (internal transcribed spacer [ITS] regions 1 and 4) based on conserved regions of the ribosomal RNA (rRNA) genes of fungi were synthesized. Use of the primers in the polymerase chain reaction (PCR) resulted in the amplification of DNA products from the genomes of sugar beet fungal pathogens of a size consistent with the amplification of the actin gene and rRNA gene sequences, respectively, in these fungi. With one primer pair (5FWDACT and MIDREVACT) directed to the actin gene, the major products amplified from the DNA of Aphanomyces cochlioides, Pythium ultimum, Cercospora beticola, Phoma betae, Fusarium oxysporum, and Rhizoctonia solani were of the sizes of 0.9, 0.9, 1.1, 1.1, 1.2 and 1.7 kilobase pairs (kbp), respectively, whereas no product was generated from the DNA of sugar beet (Beta vulgaris L.). Restriction endonuclease digestion of products amplified using 5FWDACT and MIDREVACT permitted the differentiation of A. cochlioides from A. euteiches. Use of ITS1 and ITS4 in PCR reactions employing the same template DNAs and reaction conditions yielded single products of $0.7,0.8,0.5,0.5,0.6$, and $0.7 \mathrm{kbp}$, respectively, as well as a $0.7-\mathrm{kbp}$ product from DNA of sugar beet. The data indicate that actin and rRNA gene sequences are appropriate targets for the development of PCR-based strategies for distinguishing sugar beet fungal pathogens at the genus level. The presence of A. cochlioides DNA in extracts of diseased sugar beet seedlings was detected using PCR with primers 5FWDACT and MIDREVACT.
\end{abstract}

The yields of sugar beet can be compromised severely by diseases caused by fungal pathogens (4). This can result from poor stand establishment due to seedling pre- and post-emergence damping off, caused principally by Pythium spp., Aphanomyces cochlioides, and Rhizoctonia solani. Additionally, adult plant root rots, caused by $A$. cochlioides and $R$. solani, and leaf spot, caused by Cercospora beticola, can reduce sugar beet sucrose accumulation and tonnage (4). Seed treatments show effectiveness in the control of Pythium damping off and black-root seedling disease caused by $A$. cochlioides (2). Leaf-

Corresponding author: J. J. Weiland Email: weilandj@fargo.ars.usda.gov

Mention of a trademark or proprietary product does not constitute a guarantee or warrantee of the product by the United States Department of Agriculture or imply approval to the exclusion of other products that may also be suitable.

Accepted for publication 5 January 2000.

Publication no. D-2000-0218-02R

This article is in the public domain and not copyrightable. It may be freely reprinted with customary crediting of the source. The American Phytopathological Society, 2000. spot disease continues to be controlled though foliar fungicide application, although resistance of the fungus to the benzimidazole fungicides and tolerance to triphenyltin hydroxide has been documented $(3,26)$. No chemical means currently are implemented for controlling adult plant root rot in sugar beet, and plant resistance to root-rot pathogens has been difficult to incorporate into high-yielding varieties (4).

The accurate identification of pathogens that cause crop disease is critical to the implementation of successful disease-management strategies. Fungi infecting sugar beet often are readily identified by the asexual or sexual spores that they produce. Conidiophores and conidia of $C$. beticola can be seen within lesions on infected leaves using light microscopy $(4,26)$, although lesions devoid of these structures might be confused with leaf spot caused by Phoma betae and Ramularia beticola (25). Fungal pathogens causing damping off and root rot of sugar beet are not so easily distinguished, however. Detection methods usually require culture of the diseased tissue to permit growth of the disease-causing organism, followed by identification of the organism by microscopy. This method can lead to the misidentification of a fungus due to lack of a distinguishing asexual or sexual spore type and can be confounded by the presence of saprophytic organisms that may outgrow the pathogen in culture.

Interests in our laboratory include the development of more sensitive and rapid methods for the detection and differentiation of sugar beet fungal pathogens, as well as the functional analysis of sugar beet pathogenesis by fungi. To this end, we are engaged in experiments aimed at cloning and characterizing the actin genes from the fungi C. beticola, A. cochlioides, and Rhizoctonia solani. The gene for actin is conserved throughout the eukaryota; therefore, it has received attention as a "molecular clock" gene for studies examining organism phylogeny (16). Typically, actin is a highly expressed gene, making the promoter of this gene valuable for the expression of heterologous genes in gene fusions (13). The rRNA genes of organisms also have been used in phylogenetic studies, although they have been less useful for the expression of foreign genes (14). Examination of polymorphisms in amplified DNA of the internal transcribed spacer (ITS) region of rRNA genes in the present study provides a benchmark against which diversity in the actin gene can be compared (24). Genes encoding rRNA have been used extensively in polymerase chain reaction (PCR) tests designed to differentiate fungal phytopathogens $(5,6,8-10,12,18,20-$ 22).

The current study was undertaken to determine whether common fungal pathogens of sugar beet could be distinguished by PCR using primers directed to the coding region of the actin gene and the ITS region of the rRNA genes. The ability to detect $A$. cochlioides in infected sugar beet seedlings also was investigated. Information generated from the study would be useful in the development of PCR-based disease diagnostics and in the application of DNA sequence data to fungal phylogenetics.

\section{MATERIALS AND METHODS}

Fungal isolates and primer design. Fungal isolates were maintained on potato dextrose agar (PDA), except for isolates of A. cochlioides and A. euteiches, which were maintained on cornmeal agar plates and stored in oatmeal broth (Table 1). Other fungi used in the study were stored on sterile barley grain at $-80^{\circ} \mathrm{C}$ to minimize genotype changes that might occur 
from excessive isolate transfer (19). Growing cultures were incubated in the dark at $22^{\circ} \mathrm{C}$. Pathogenicity of fungal isolates, except for A. euteiches, on sugar beet was confirmed using standard inoculation procedures (19); pathogenicity of $\mathrm{A}$. $\mathrm{eu}$ teiches isolates was confirmed on pea (Pisum sativum cv. Wando).

Nucleotide sequences of the actin genes of Sacchromyces cerevisae, Phytophthora infestans, Trichoderma reesei, Aspergillus nidulans, and Puccinia graminis were obtained from the Genbank sequence database. Positioning of conserved amino-acid sequences encoded by actin genes (16) onto the gene sequences from these fungi permitted the identification of nucleotide sequences conserved amongst these genes (Fig. 1). Consensus sequences for each of were generated and primers were designed based upon these sequences. Primers 5FWDACT and MIDFWDACT were designed to be homologous to the sequence blocks near the $5^{\prime}$ end of the coding strand of the gene, whereas primers MIDREVACT and 3REVACT were designed to be complementary to the sequence blocks near the $3^{\prime}$ end of the coding strand of the gene (Fig. 1). Primers ITS1 (5'TCCGTAGGTGAACCTGCGG3') and ITS4 (5'TCCTCCGCTTATTGATATGC3') are directed to conserved regions in rRNA genes of fungi (Fig. 1B; 24).

DNA preparation and PCR. Fungal mycelium was grown to near confluency on PDA or corn meal agar plates. Sterile four regions in the actin structural gene

potato dextrose broth (PDB) was poured onto the mycelial mat and the mycelium was scraped from the agar surface using a sterile razor blade. The suspension was transferred to a sterile Petri dish and incubated at $22^{\circ} \mathrm{C}$ in the dark for $20 \mathrm{~h}$. Mycelia were captured by filtration of the suspension through Miracloth (Calbiochem, La Jolla, CA). After several rinses with distilled, sterile water, mycelia were transferred to a mortar containing quartz sand (-50+70 mesh, Sigma-Aldrich, St. Louis). Preparation of fungal DNA was according to Weiland (23). Extraction buffer $(0.1 \mathrm{M}$ TRIS-HCl, pH 8.0, $20 \mathrm{mM} \mathrm{Na}{ }_{2}$ EDTA, 0.5 $\mathrm{M} \mathrm{NaCl}$, and $1 \%$ sodium dodecylsulfate) was added to the mortar and the mixture was homogenized. The homogenate was extracted with buffer saturated phenol:chloroform:isoamyl alcohol (25:24:1) and the aqueous phase was precipitated with isopropanol. The precipitate was collected by centrifugation and the pellet was washed with $95 \%$ ethanol and dried in vacuo. The pellet was resuspended in $10 \mathrm{mM}$ TRIS-HCl, pH 8.0, $1.0 \mathrm{mM}$ $\mathrm{Na}_{2}$ EDTA (TE), including ribonuclease A at $20 \mu \mathrm{g} / \mathrm{ml}$, and was incubated for 30 min at $37^{\circ} \mathrm{C}$. After a second extraction with phenol:chloroform:isoamyl alcohol (25:24:1), the DNA was precipitated from the aqueous phase using ethanol and ammonium acetate and the precipitate again was collected by centrifugation. The final DNA pellet was washed with 95\% ethanol, dried, and dissolved in 0.1 $\mathrm{ml}$ of TE.

Table 1. Isolates of fungal pathogens used in the development of a polymerase chain reaction differentiation assay

\begin{tabular}{lllll}
\hline Fungal pathogen & \multicolumn{1}{c}{ Isolate } & Bait plant & \multicolumn{1}{c}{ Region } & \multicolumn{1}{c}{ Source } \\
\hline Aphanomyces cochlioides & $17-1 \mathrm{z}$ & Sugar beet & Minnesota & C. Windels \\
& $19-1 \mathrm{z}$ & Sugar beet & Minnesota & C. Windels \\
& $20-1 \mathrm{z}$ & Sugar beet & Minnesota & C. Windels \\
& Russ 2A & Sugar beet & Michigan & J. Halloin \\
& Bera 3A & Sugar beet & Michigan & J. Halloin \\
& Bob 24 & Sugar beet & Michigan & J. Halloin \\
A. euteiches & 174 & Pea & Minnesota & C. Windels \\
& 467 & Pea & Minnesota & C. Windels \\
Cercospora beticola & MM35 & Pea & Minnesota & C. Windels \\
& $98-23$ & Sugar beet & North Dakota & W. Bugbee \\
& $898 \mathrm{~A}$ & Sugar beet & Minnesota & J. Weiland \\
Fusarium oxysporum & $898 \mathrm{~B}$ & Sugar beet & Minnesota & J. Weiland \\
& $898 \mathrm{C}$ & Sugar beet & Minnesota & J. Weiland \\
& $898 \mathrm{~A}$ & Sugar beet & Minnesota & J. Weiland \\
Phoma betae & $898 \mathrm{~B}$ & Sugar beet & Minnesota & J. Weiland \\
& $898 \mathrm{C}$ & Sugar beet & Minnesota & J. Weiland \\
& $11 \mathrm{~A} 11$ & Sugar beet & Minnesota & W. Bugbee \\
& $3 \mathrm{~A} 15$ & Sugar beet & Minnesota & W. Bugbee \\
& $10 \mathrm{~A} 13$ & Sugar beet & Minnesota & W. Bugbee \\
& $1098 \mathrm{~A}$ & Sugar beet & Montana & J. Weiland \\
& $1098 \mathrm{~B}$ & Sugar beet & Montana & J. Weiland \\
& $1098 \mathrm{C}$ & Sugar beet & Montana & J. Weiland \\
& $898 \mathrm{~A}$ & (Soil) & Minnesota & J. Weiland \\
& $898 \mathrm{~B}$ & (Soil) & Minnesota & J. Weiland \\
& $898 \mathrm{C}$ & (Soil) & Minnesota & J. Weiland \\
& "heterothallic" & Potato & North Dakota & B. Salas \\
& $153-7$ & Potato & North Dakota & B. Salas \\
& $2 \mathrm{~A} 13$ & Sugar beet & Minnesota & W. Bugbee \\
& R9 & Sugar beet & Colorado & E. Ruppel \\
& $898 \mathrm{~A}$ & Sugar beet & Minnesota & J. Weiland \\
& $898 \mathrm{~B}$ & Sugar beet & Minnesota & J. Weiland \\
\hline
\end{tabular}

Fungal DNA preparations for use in PCR were adjusted to a concentration of $1.0 \mu \mathrm{g} / \mathrm{ml}$ and oligonucleotide primers were diluted to $10 \mu \mathrm{g} / \mathrm{ml}$. PCR reactions, optimized according to the recommendations of Innis and Gelfand (7), were performed in a volume of $50 \mu \mathrm{l}$ and included $10 \mathrm{ng}$ of fungal DNA, $50 \mathrm{ng}$ of each forward and reverse primer, $10 \mathrm{mM}$ TRIS$\mathrm{HCl}$ (pH 9.0), $50 \mathrm{mM} \mathrm{KCl,} \mathrm{0.1 \%} \mathrm{Triton} \mathrm{X-}$ $100,1.5 \mathrm{mM} \mathrm{MgCl} 2,0.1 \mathrm{mM}$ each of $\mathrm{d}(\mathrm{G}, \mathrm{A}, \mathrm{T}, \mathrm{C}) \mathrm{TP}$, and 2 units of Taq DNA polymerase (Promega Corp., Madison, WI). Samples were incubated in a thermocyler (Model PTC100V, MJ Research, Watertown, MA) for 40 cycles with cycling parameters of $94^{\circ} \mathrm{C}$ for $1 \mathrm{~min}, 45$ to $55^{\circ} \mathrm{C}$ for $1 \mathrm{~min}$, and $72^{\circ} \mathrm{C}$ for $2 \mathrm{~min}$. Reactions were terminated by the addition of loading buffer $(10 \times=0.01 \%$ bromophenol blue, 50\% glycerol, 0.5 M TRIS, pH 8.5, $0.5 \mathrm{M}$ boric acid, and $10 \mathrm{mM}$ EDTA), except for cases where samples were digested with restriction endonucleases prior to electrophoresis. A total of $10 \%$ of each PCR reaction was loaded onto a $1 \%$ agarose gel containing TRIS-borate-EDTA (TBE) electrophoresis buffer (1) and electrophoresed at $10 \mathrm{~V} / \mathrm{cm}$.

Amplified products were digested with restriction endonucleases by combining 10 $\mu \mathrm{l}$ of each PCR reaction, 2 units of each of the enzymes Alu1, HaeIII, and Msp 1 (American Allied Biochemical, Aurora, $\mathrm{CO})$, and $2 \mu \mathrm{l}$ of restriction enzyme buffer (10 mM TRIS-HCl, pH 7.8, $10 \mathrm{mM}$ $\mathrm{MgCl}_{2}, 50 \mathrm{mM} \mathrm{NaCl}$, and $1 \mathrm{mM} \beta$-mercaptoethanol), and adjusting the solution to $20 \mu \mathrm{l}$. The digests were incubated for $2 \mathrm{~h}$ at $37^{\circ} \mathrm{C}$, terminated by the addition of $2.3 \mu \mathrm{l}$ of $10 \times$ loading buffer, and the products were separated on a $6 \%$ polyacrylamide gel using 1× TBE electrophoresis buffer (1). Gels were photographed using an AlphaInnotech Chemimager 4000 gel documentation system.

Plant inoculation and disease diagnosis. Sugar beet seed of cv. Ultramono was seeded in 6-inch pots of peat-perlite (Sunshine Mix \#1) at a rate of 5 seeds/pot. At 7 days post-planting, an agar plug containing a fresh culture of Aphanomyces cochlioides was placed just below the soil surface and next to the seedlings. Seedlings were watered twice daily with tap water after the day of inoculation. By 4 to 7 days post-inoculation, symptoms of seedling black root were observed.

Extracts from diseased and uninoculated (healthy) seedlings were prepared based on a modification of the procedure by SaghaiMaroof et al. (17) by surface sterilizing the excised seedling hypocotyl and boiling for $10 \mathrm{~min}$ in CTAB extraction buffer (100 $\mathrm{mM}$ TRIS-HCl, pH 8.0, $2 \%$ [wt/vol] cetyltrimethylammonium bromide, $1.4 \mathrm{M}$ $\mathrm{NaCl}, 20 \mathrm{mM}$ EDTA, and $1 \%$ [wt/vol] soluble polyvinylpyrrolidone) at a rate of 1 $\mathrm{ml}$ of buffer/4 excised hypocotyls. The solution was extracted once with an equal 
P.inf

A.nid

T.rees

S.cerv

P.gram
"5FWDACT"

5' GT ATG TGC AAG GCC GGT TT 3' 19-mer

TCC GGT ATG TGC AAG GCC GGT TTC

TCG GGT ATG TGC AAG GCC GGT TTC

TCT GGT ATG TGC AAG GCC GGT TTC

TCT GGT ATG TGT AAA GCC GGT TTT

TCG GGT ATG TGC AAA GCC GGT TTC
P.inf
A.nid
T. rees
S.cerv
P.gram

\section{"MIDFWDACT"}

5' TGG CAC CAC ACC TTC TAC AA 3' 20-mer

ATC TGG CAC CAC ACC TTC TAC AAC GAG CTG CGT

ATT TGG CAC CAC ACA TTC TAC AAC GAG CTT CGT

ATC TGG CAC CAC ACC TTC TAC AAT GAG CTG CGT

ATC TGG CAT CAT ACC TTC TAC AAC GAA TTG AGA

ATC TGG CAT CAC ACC TTC TAC AAC GAG CTC CGA

\section{3' end of actin coding sequence:}

$$
\begin{aligned}
& \text { P.infe } \\
& \text { A.nidu } \\
& \text { T.rees } \\
& \text { S.cerv } \\
& \text { P.gram } \\
& \text { 23-mer }
\end{aligned}
$$

P.inf

A.nid

T.rees

S. cerv

P.gram

19-mer

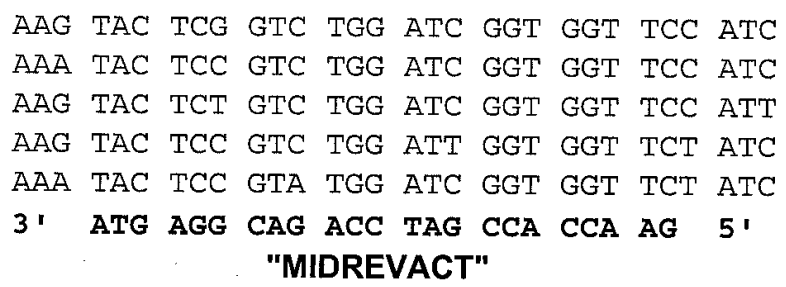

AAG TAC TCG GTC TGG ATC GGT GGT TCC ATC AAA TAC TCC GTC TGG ATC GGT GGT TCC ATC AAG TAC TCT GTC TGG ATC GGT GGT TCC ATT AAG TAC TCC GTC TGG ATT GGT GGT TCT ATC AAA TAC TCC GTA TGG ATC GGT GGT TCT ATC 3' ATG AGG CAG ACC TAG CCA CCA AG 5' "MIDREVACT"

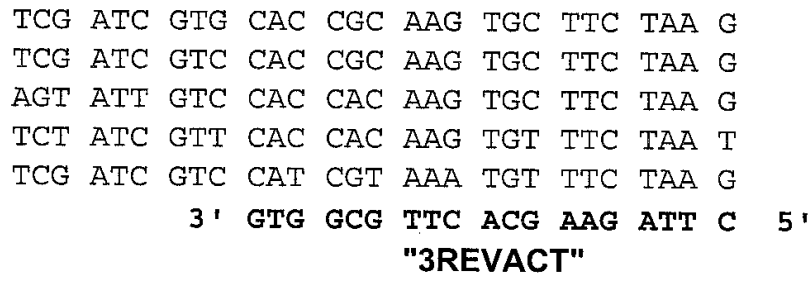

B

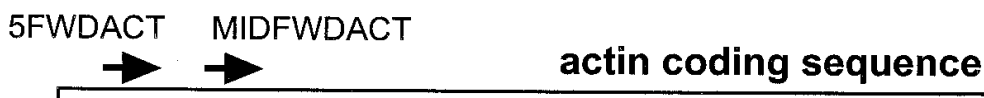

MIDREVACT

3REVACT

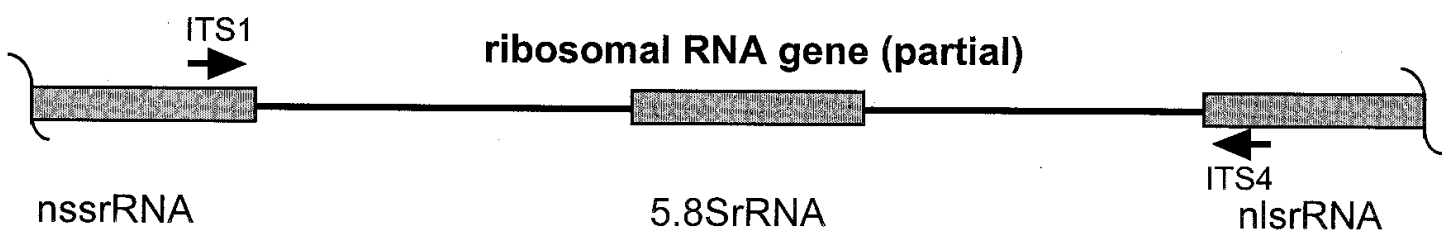

Fig. 1. (A) Alignment of actin gene sequences from selected filamentous fungi and design of primers for the polymerase chain reaction. Deduced protein sequences from gene sequences were visually aligned according to highly conserved regions of actin across eukaryotes. The DNA sequences in these regions then were aligned and a consensus sequence, derived from this alignment, was used as the basis for primer design (bold type). Primer designation is presented above and below the primer sequence. (B) Diagrammatic representation of location of primers on a generic actin gene and rRNA gene. Most fungal actin genes contain introns which are not shown here (16). Regions of the primary rRNA removed by splicing within the internal transcribed spacer regions are depicted as lines; shaded boxes represent sequences that become the mature rRNAs (nls $=$ nuclear large subunit, nss $=$ nuclear small subunit). 
volume of chloroform:isoamyl alcohol (24:1) and was precipitated with 0.6 vol. of isopropanol. The final nucleic acid pellet was washed with $95 \%$ ethanol, dried, and resuspended in $50 \mu \mathrm{l}$ of TE. The preparation $(1 \mu \mathrm{l})$ was used as template in the PCR reaction using the conditions described above and the primers 5FWDACT and MIDREVACT.

\section{RESULTS AND DISCUSSION}

Amplification of actin gene sequences. Initial experiments performed with primers directed to the actin gene indicated that an annealing temperature of $55^{\circ} \mathrm{C}$ during PCR permitted the amplification of DNA products from genomic DNA from most of the fungi examined without the amplification of products from sugar beet genomic DNA. A $50^{\circ} \mathrm{C}$ annealing temperature was necessary for the consistent generation of amplified DNA by PCR from the genomic DNA of Rhizoctonia solani, although DNA products were amplified from genomic DNA of sugar beet in some of the experimental replications at this annealing temperature. The PCR conditions for the differentiation of fungi from pure culture using actin-based primers, therefore, employed a $50^{\circ} \mathrm{C}$ annealing temperature, whereas a $55^{\circ} \mathrm{C}$ annealing temperature was used in the detection of $A$. cochlioides in diseased seedlings. Of the actin-based primers tested, primers 5FWDACT and MIDREVACT gave the most consistent amplification products in these tests; only results using this pair of actin-based primers are presented.

A single DNA product was amplified from the genomic DNA of Pythium ultimum, C. beticola, and Phoma betae when using primers 5FWDACT and MIDREVACT (Fig. 2A). The amplification of Fusarium oxysporum DNA generated a major product at 1.2 kilobase pairs $(\mathrm{kbp})$, with weakly amplified products at 0.7 and $0.6 \mathrm{kbp}$. Whereas only one weakly amplified product $(0.4 \mathrm{kbp})$ was generated from A. cochlioides DNA in addition to the major 0.9-kbp product, weak products of sizes $0.2,0.5,0.8$, and $1.6 \mathrm{kbp}$ were amplified from two R. solani (898A and 898B) isolates and products of sizes $0.4,0.7$, and 1.6 $\mathrm{kbp}$ were amplified from a third $R$. solani (2A13) isolate. From the examination of several cloned actin genes, the coding region for actin appears to be minimally around $1.0 \mathrm{kbp}$ (16). The faster-migrating products of the PCR reactions, therefore, could be the result of mispriming by the actin gene-based primers or of correct priming on actin pseudogene or other sequences. Nevertheless, the application of PCR using 5FWDACT and MIDREVACT to the fungi examined here resulted in the generation of DNA products of differing
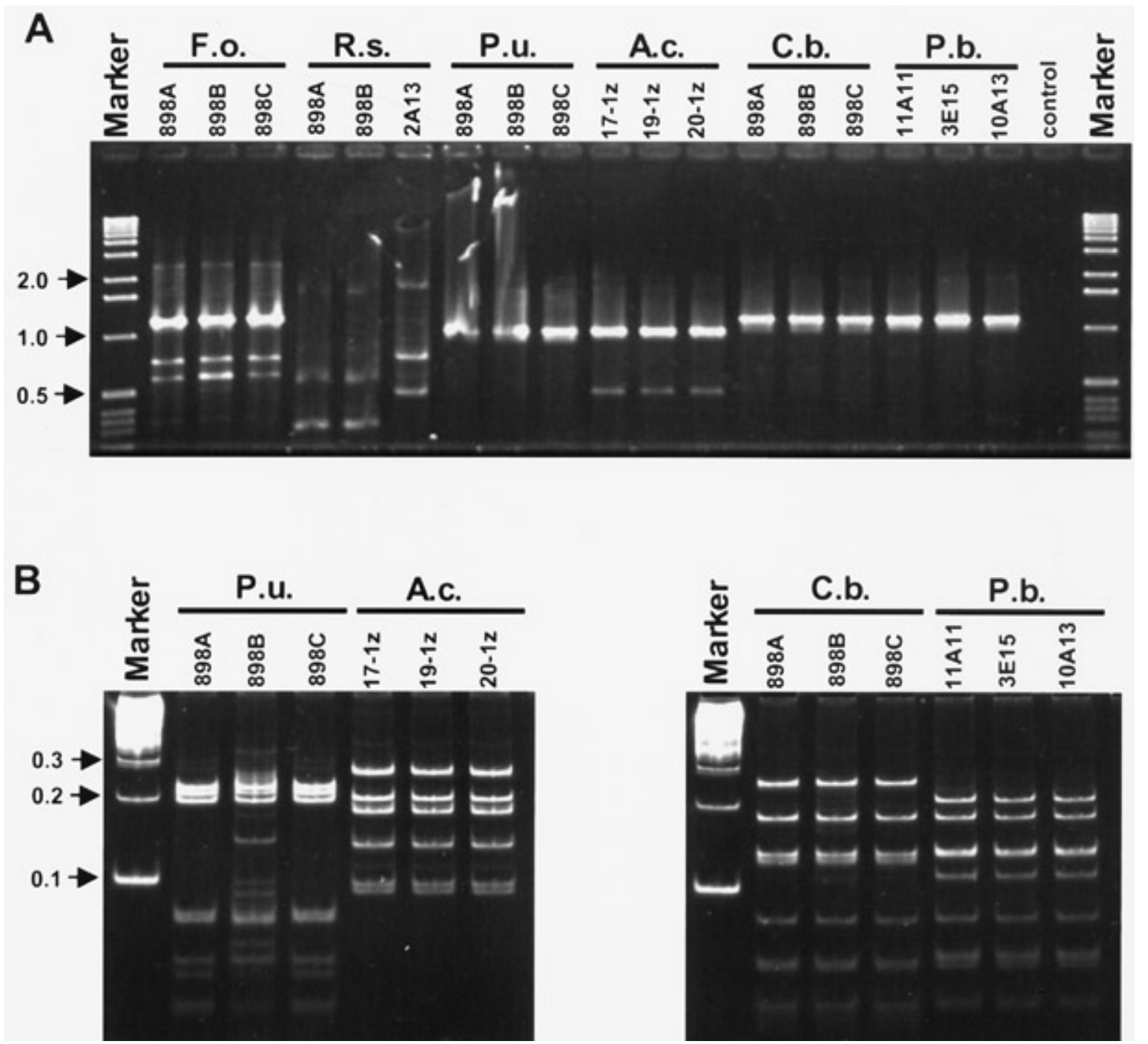

Fig. 2. (A) Amplification of DNA from the genomes of representative sugar beet fungal pathogens with actin gene-specific primers and (B) analysis of restriction enzyme digestion products. Oligonucleotide primers 5FWDACT and MIDREVACT were used in all reactions. Reactions were performed in duplicate and a sample of the products was analyzed by agarose gel electrophoresis (A). In A, the 1-kilobase-pair (kbp) ladder (Life Technologies, Gaithersburg, MD) was co-electrophoresed as a size standard (Marker). Abbreviations for lane labeling are F.o. (Fusarium oxysporum), R.s. (Rhizoctonia solani), P.u. (Pythium ultimum), A.c. (Aphanomyces cochlioides), C.b. (Cercospora beticola), and P.b. (Phoma betae) with isolate designators included directly above each lane. In B, a subset of the products shown in A were subjected to digestion with a restriction endonuclease cocktail containing Alu1, HaeIII , and Msp 1 prior to electrophoresis on a 6\% polyacrylamide gel. The 100-bp ladder was co-electrophoresed as a size standard (Marker). 
molecular size, enabling these pathogens to be distinguished. Sequence analysis of the $1.6-\mathrm{kb}$ product generated from $R$. solani DNA should yield information permitting the design of primers for the optimal amplification of the actin gene in this organism. Sequence comparison analysis of DNA amplified in our laboratory from $A$. cochlioides and the fungal entomopathogen Metarhizium anisoplae using the primers 5FWDACT and MIDREVACT indicates that the DNA amplified in this study is, indeed, that coding for the actin protein (not shown).

For most of the PCR tests described above, products amplified with primer pair 5FWDACT and MIDREVACT differed in their migration after electrophoresis between the organisms tested (Fig. 2A). The major product amplified from the genomic DNA of $C$. beticola, however, was of a similar size to that amplified from the genomic DNA of $P$. betae. Likewise, the PCR product generated from the genomic
DNA of Pythium ultimum was of a similar size to that generated from $A$. cochlioides DNA. Sugar beet leaf spot might be misdiagnosed as being caused by $C$. beticola in instances where Phoma betae is the causal agent. Likewise, seedling damping off caused by $A$. cochlioides might be misdiagnosed as Pythium damping off. Additional sequence differences in the actin genes of the respective pathogen pairs need to be revealed, therefore, if the PCR assay is to be sufficiently discriminating.

The digestion of the 1.2-kbp actin gene products common to $C$. beticola and $P$. betae with a mixture of the restriction endonucleases Alu1, Msp1, and HaeIII yielded polymorphisms that permitted the differentiation of these two pathogens based on the isolates examined (Fig. 2B). Electrophoretic patterns generated by restriction digest of amplified products were consistent between the isolates of the fungal genus under examination. A total of seven and eight restriction-enzyme prod- ucts generated from the digestion of the 1.2-kbp product characterizing $C$. beticola and $P$. betae, respectively, were resolved by native polyacrylamide gel electrophoresis. Five of the digestion products from each of the pathogens had a similar migration in the gel. Two of the digestion products originating from the amplification of $C$. beticola actin gene sequences were absent from that of $P$. betae, whereas three of the digestion products originating from the amplification of $P$. betae actin gene sequences were absent from that of $C$. beticola.

The digestion with Alu1, Msp1, and Hae III of the 0.9-kbp product common to the amplified actin gene sequences of $A$. cochlioides and Pythium ultimum yielded distinguishing DNA banding patterns to a greater degree than that in the comparison of C. beticola and Phoma betae. Digestion of the $0.9-\mathrm{kbp}$ product yielded eight and six bands resolved by electrophoresis for Pythium ultimum and A. cochlioides, re-

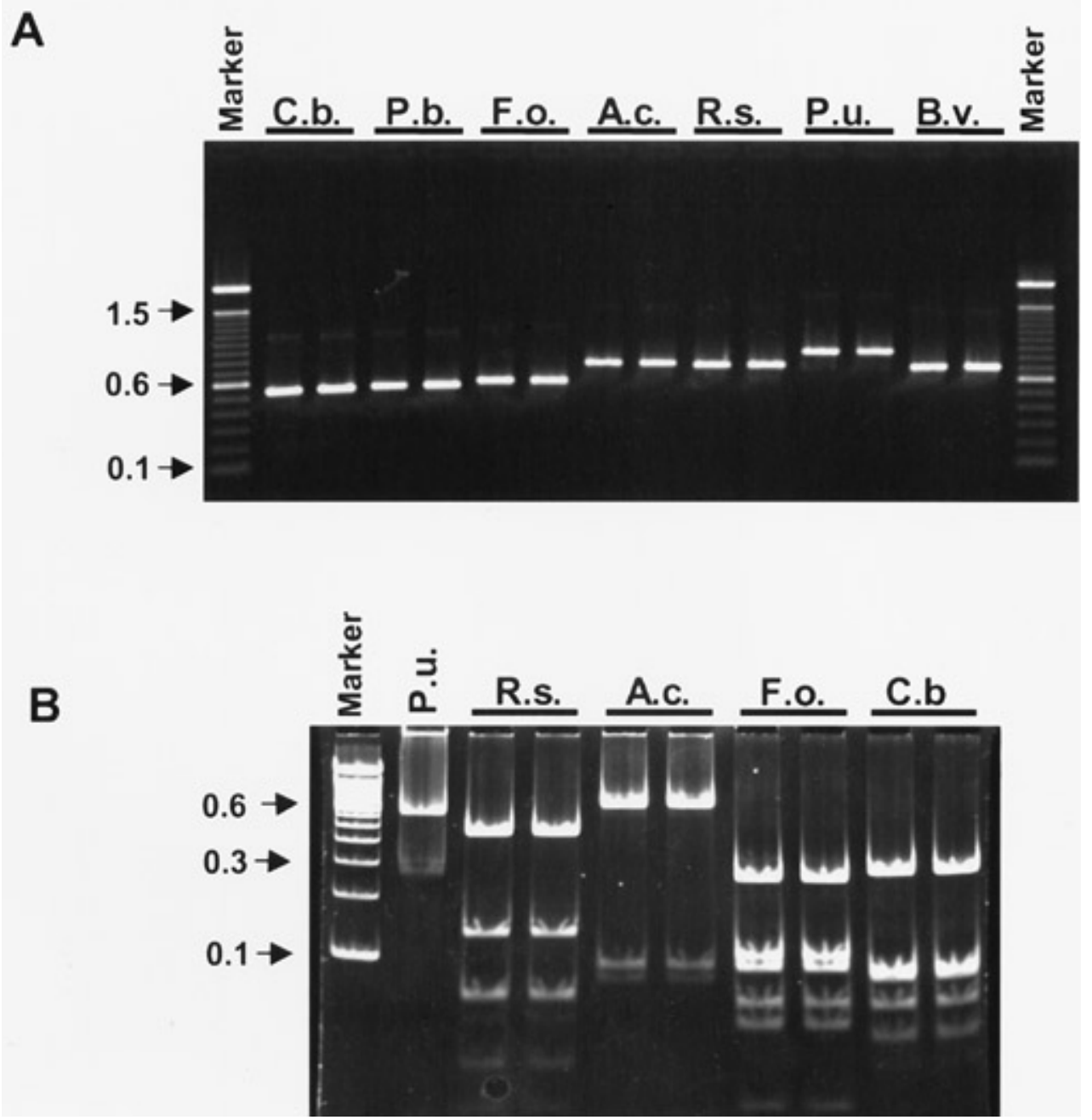

Fig. 3. (A) Amplification of DNA from the genomes of several sugar beet fungal pathogens with rRNA gene-specific primers and (B) analysis of restriction enzyme digestion products. Oligonucleotide primers ITS 1 and 4 were used in the amplification. Reactions were performed in duplicate and a sample of the products was analyzed by agarose gel electrophoresis (A). Abbreviations for lane labeling are F.o. (Fusarium oxysporum), R.s. (Rhizoctonia solani), P.u. (Pythium ultimum), A.c. (Aphanomyces cochlioides), C.b. (Cercospora beticola), P.b. (Phoma betae), and B.v. for sugar beet (Beta vulgaris L.) DNA, with isolate designators included directly above each lane. In B, a subset of the products shown in A were digested with a restriction endonuclease mixture of Alu1, HaeIII, and Msp 1 prior to electrophoresis on a $6 \%$ polyacrylamide gel. For both A and B, the 100-base-pair ladder was co-electrophoresed as a size standard (Marker). 
spectively. Only one of the bands generated (approximately $200 \mathrm{bp}$ ) appeared common to the two pathogens. Sequence polymorphisms in the actin gene within $P$. ultimum are suggested by the different bands observed for isolate $898 \mathrm{~B}$ as compared to isolates $898 \mathrm{~A}$ and $898 \mathrm{C}$ after restriction-enzyme digest of the PCR products (Fig. 2B). The additional products may represent amplification of a distinct haplotype of the actin gene in this isolate of $P$. ultimum. Nevertheless, the actin gene appears to possess sufficient sequence divergence between fungi of different genera for the development of PCR-based methods aimed at differentiating sugar beet fungal pathogens.

Amplification of rRNA gene sequences. Much focus in molecular phylogenetics has been placed on sequences of the ITS region of rRNA genes $(14,24)$. Use of the primers ITS1 and ITS4 directed to the ITS region of the rRNA gene by PCR generated amplification products of 0.5 to $0.8 \mathrm{kbp}$ for the sugar beet fungal pathogens examined in this study. Only the $50^{\circ} \mathrm{C}$ annealing temperature was used, which yielded abundant, discrete amplification products for all fungi tested. Approximate sizes of the products amplified from the ITS region were $0.5 \mathrm{kbp}$ for $C$. beticola, $0.7 \mathrm{kbp}$ for $A$. cochlioides, $0.5 \mathrm{kbp}$ for $F$. oxysporum, $0.7 \mathrm{kbp}$ for $R$. solani, $0.8 \mathrm{kbp}$ for P. ultimum, $0.6 \mathrm{kbp}$ for Phoma betae, and $0.7 \mathrm{kbp}$ for sugar beet (Beta vulgaris) (Fig. 3A). Product sizes are consistent with those previously reported for the ITS re- gions in other Fusarium spp. (18), as well as for Pythium ultimum (8) and $R$. solani (10). Based on the study by Ward et al. (22), amplification of the ITS region of Polymyxa betae, the fungal vector of Beet necrotic yellow vein virus (BNYVV; causal agent of beet rhizomania), would yield a product of approximately $0.5 \mathrm{kbp}$, which would be distinguishable from the ITS products generated from many of the fungi analyzed here. The $0.7-\mathrm{kbp}$ product amplified from sugar beet DNA (Fig. 3A) agrees with the data presented by Ward et al. (22) using a similar primer pair.

As with products amplified from the actin gene using primers 5FWDACT and MIDREVACT, some of the products amplified from the rRNA gene ITS region of two different fungi were of a similar size (Fig. 3A). Digestion of these products with the endonuclease mixture of AluI, HaeIII, and $M s p I$ revealed the presence of nucleotide differences in these products. As above, patterns generated by restriction digest of amplified products were consistent between the isolates of the fungal genus being examined (not shown). Thus, the analysis of restriction fragment length polymorphisms of the products amplified by PCR using primers ITS1 and ITS4 give an additional level of resolution in the differentiation of sugar beet fungal pathogens. It should be noted that the ITS primers used in the present test would be of limited use in the detection of fungi within sugar beet, because a product of a size similar to that observed for the fungi tested

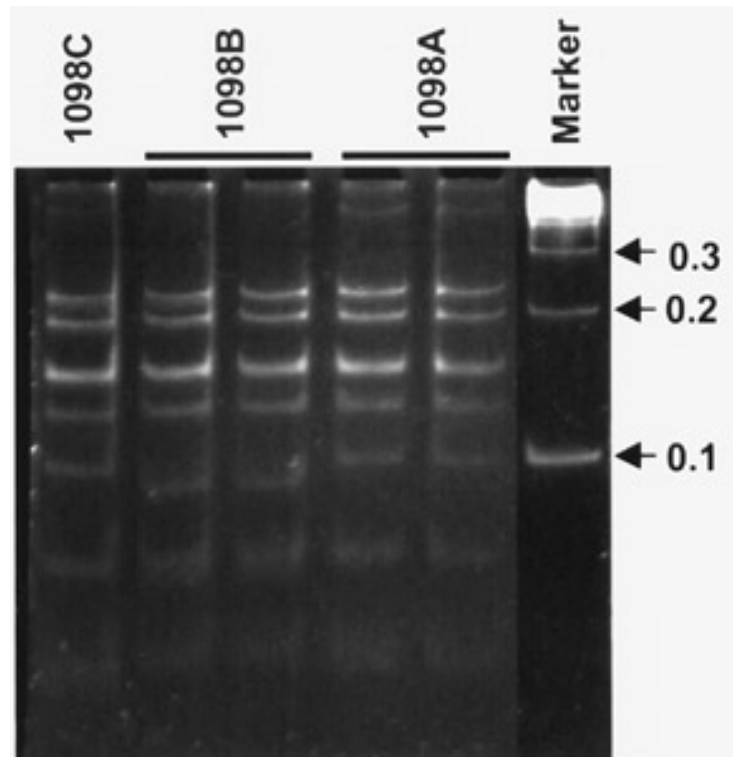

Fig. 4. Native polyacrylamide gel $(6 \%)$ of restriction endonuclease-digested products of amplified actin gene sequences from a fungus isolated from diseased sugar beet. Three isolates (1098A, 1098B, and 1098C), each from a separate, diseased sugar beet plant, were cultured in potato dextrose broth. Total DNA prepared from fungal mycelia was used as template in polymerase chain reactions that included primers 5FWDACT and MIDREVACT. The amplified product from each isolate of approximately 1.1 kilobase pairs (kbp) (not shown) was digested with a mixture of the restriction enzymes AluI, HaeIII, and MspI. Digestion products were fractionated by electrophoresis and the gel was photographed. The 100-bp ladder was co-electrophoresed as a size standard (Marker). Compare the DNA banding pattern to that generated from Phoma betae DNA in Figure 2B. Note the slightly faster migration of the approximately $0.1-\mathrm{kb}$ product originating from isolate $1098 \mathrm{~B}$ as compared to those originating from isolates $1098 \mathrm{C}$ and 1098A. was amplified from uninfected sugar beet. Nevertheless, the amplification of DNA from this region followed by digestion with restriction endonucleases remains useful for the discrimination of pure isolates of the fungi investigated here and elsewhere (24).

Identification of $P$. betae isolated from field samples of diseased sugar beet. In October of 1998, diseased mature sugar beets were received from growers in the Yellowstone River valley of Montana. Petioles of the leaves had a blackened appearance and many of the older leaves had senesced. Surface-sterilized petiole sections were placed onto PDA. After 2 days, the hyphal tips of the fungus growing out of the petiole were transferred to PDB and to a fresh plate of PDA. At 3 days postplating, DNA was prepared from the liquid culture of the fungus and PCR assays, using the primer pairs 5FWDACT-MIDREVACT and ITS1-ITS4 in separate reactions, were performed. By the evening of the same day, electrophoresis of the PCR products (not shown) combined with the disease symptoms suggested that the isolated organism was Phoma betae. At 4 days after plating of the petiole sections, restriction-enzyme digestion of the PCR products yielded patterns supporting the probability that the isolated fungus was $P$. betae (Fig 4). At 10 days after the plating of the fungus on PDA, pycnidia were observed under the mycelia. Spore discharge from isolated pycnidia was characteristic of that described for $P$. betae (25). The example illustrates the usefulness of the information obtained using the PCR assay in generating rapid information leading to the identification of organisms associated with, or causing, a disease. The data presented further indicate the existence of sequence polymorphism at the actin locus within P. betae (Fig. 4).

Differentiation of $A$. cochlioides from A. euteiches and detection of $A$. cochlioides in diseased sugar beet seedlings. The pathogen A. euteiches can be found in association with legumes in regions where sugar beet is grown. A host-range bioassay is the principle means by which $A$. cochlioides and $A$. euteiches currently are differentiated (15), although random amplified polymorphic DNA analysis has permitted the separation of these organisms based on DNA fingerprinting as well (11). A. euteiches and A. cochlioides can induce low levels of disease in the laboratory in sugar beet and pea, respectively (11); therefore, it would be informative to determine to what extent these organisms are found in association with the respective non-host plant. In order to determine if amplification of the actin gene would provide a DNA product with sufficient divergence to permit the differentiation of these two pathogens, isolates of these two pathogens were subjected to the PCR assay. The results demonstrate that amplification of 
actin gene sequences by itself is insufficient for the differentiation of these species (Fig. 5, top). Restriction-enzyme digestion of the amplified products, however, clearly shows that $A$. cochlioides and A. euteiches can be differentiated based on DNA sequence differences in the actin gene (Fig. 5, lower panel).

An anticipated use of the PCR assay is in the rapid detection of $A$. cochlioides within diseased sugar beet seedlings. To test the ability of the PCR assay to detect the presence of $A$. cochlioides DNA in an extract prepared from diseased seedlings, 1-week-old seedlings of sugar beet cv. Ultramono were either inoculated with $A$. cochlioides or left uninoculated. At 7 days post-inoculation, approximately $50 \%$ of the seedlings that had been inoculated with $A$. cochlioides began to show symptoms of seedling black-root disease. No disease symptoms were observed on uninoculated seedlings. Although the method described by Henson et al. (6) was tested for the ability to yield DNA products by PCR from diseased sugar beet seedlings, results in our laboratory indicated that a contaminant was co-extracted with the nucleic acids that inhibited PCR amplification of DNA (data not shown). For this reason, the
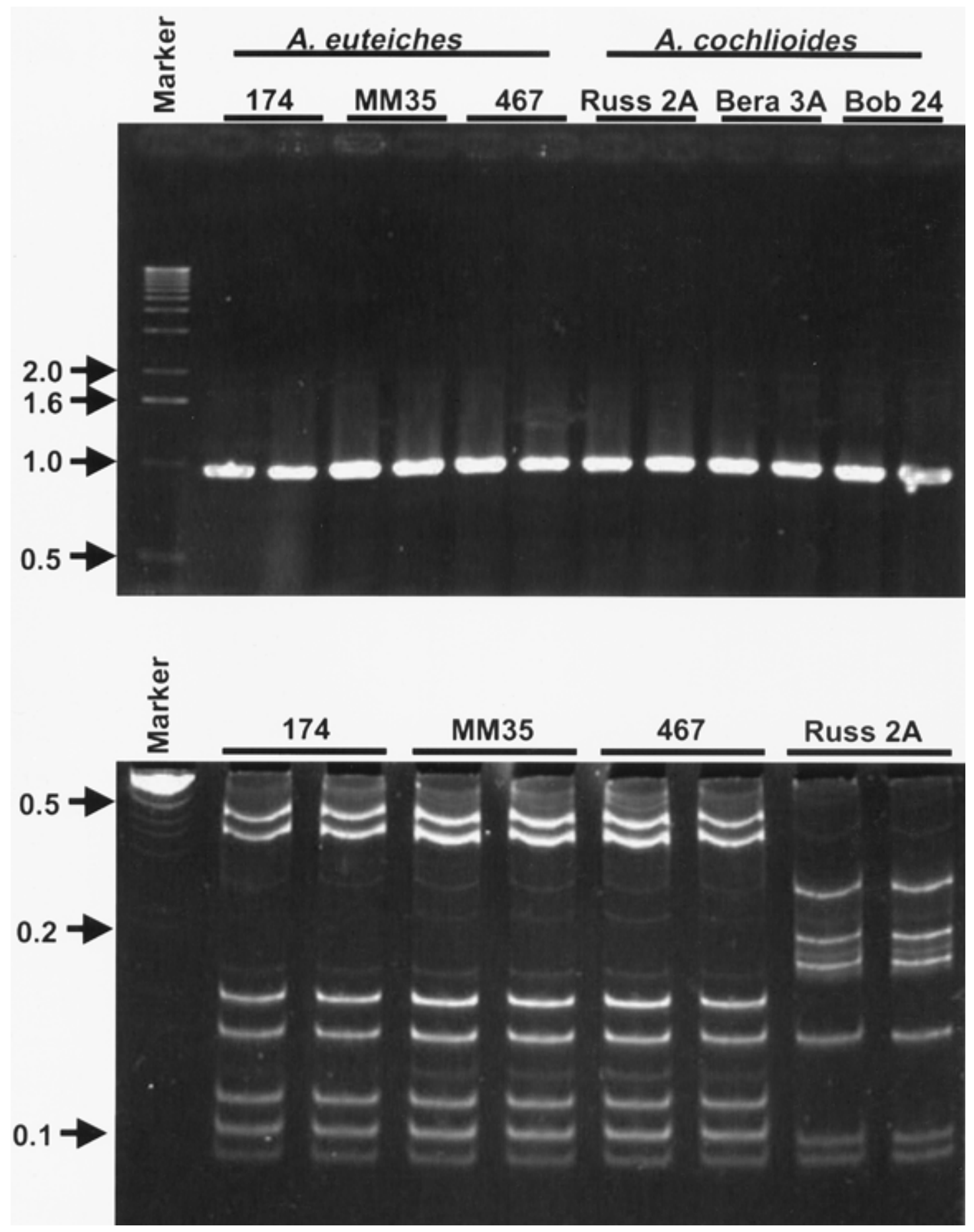

Fig. 5. Differentiation of Aphanomyces cochlioides from A. euteiches based on actin gene sequence differences. In the top panel, products amplified from the genomic DNA of A. cochlioides and A. euteiches with primers 5FWDACT and MIDREVACT were separated on a 1\% agarose gel. The 1-kilobase-pair (kbp)-ladder was co-electrophoresed as a size standard (Marker). In the lower panel, these same products were digested with a mixture of the restriction endonucleases Alu1, HaeIII, and Msp 1 before electrophoresis on a 6\% native polyacrylamide gel. For the A. cochlioides isolates, only the digest of the products from isolate Russ $2 \mathrm{~A}$ is shown. Compare the digestion pattern of Russ $2 \mathrm{~A}$ and the A. cochlioides isolates in Figure 2 to that of the A. euteiches isolates in this panel. For both panels, the 1-kbp ladder was co-electrophoresed as a size standard (Marker). 
method described by Saghai-Maroof et al. (17) was adapted to the procedure for fungal pathogen detection in diseased sugar beet. The presence of polyvinylpyrrolidone and cetyltrimethylammonium bromide during DNA extraction has been proposed to facilitate the removal of compounds that might inhibit DNA modifying enzymes (17).

Extracts were prepared from healthy and diseased seedlings from three independent experiments and the samples were subjected to the PCR assay using the primers 5FWDACT and MIDREVACT. The results of a typical experiment, in which the assay was applied to extracts from diseased tissue, clearly show amplification of DNA of a size consistent with the amplification of A. cochlioides actin DNA (Fig. 6). Restriction-enzyme digest of these products supported the contention that the amplified products contained $A$. cochlioides actin sequences (not shown). Using the annealing temperature of $55^{\circ} \mathrm{C}$, no amplified were observed.

The data suggest that the primer sequences comprising 5FWDACT and MIDREVACT are useful for distinguishing fungal pathogen from host sugar beet tissue and for detecting A. cochlioides in diseased sugar beet seedlings. It is likely that diseased, field-grown sugar beet may often harbor fungal opportunists that confound that ability to diagnose that causal agent of disease; therefore, it is cautioned that the techniques described here at the present state of development be used to complement standard disease diagnosis. Nevertheless, the positive identification of a disease-causing organism in the diseased tissue is an important element of diagnosis products from healthy, uninoculated tissue

and can be facilitated by the PCR technology outlined. Future work will be directed at the design of specific primers, based on the sequence of the cloned actin gene-specific PCR products, for the detection of $A$. cochlioides in diseased, field-grown sugar beet, in non-diseased weed hosts, and in the soil.

\section{ACKNOWLEDGMENT}

We thank G. Nielsen for providing expert technical assistance. This work was supported in part by Beet Sugar Development Foundation Project no. 620 to JJW.

\section{LITERATURE CITED}

1. Ausubel, F. M., Brent, R., Kingston, R. E., Moore, D. D., Seidman, J. G., Smith, J. A., and Struhl, K. 1989. Short Protocols in Molecular Biology. John Wiley \& Sons, New York.

2. Brantner, J. R., Windels, C. E., and Bredehoeft, M. 1998. Performance of Tachigaren seed treatment on sugarbeet varieties susceptible and resistant to Aphanomyces root rot in 1997 field trials. 1997 Sugarbeet Res. Ext. Rep. 28:273-276.

3. Campbell, L. G., Smith, G. A., Lamey, H. A., and Cattanach, A. W. 1998. Cercospora beticola tolerant to triphenyltin hydroxide and resistant to thiophanate methyl in North Dakota and Minnesota. J. Sugarbeet Res. 35:29-41.

4. Duffus, J. E., and Ruppel, E. G. 1993. Pages 346-427 in: Diseases in the Sugarbeet Crop. D. A. Cooke and R. K. Scott, eds. Chapman and Hall, London.

5. Henson, J. M., and French, R. 1993. The polymerase chain reaction and plant disease diagnosis. Annu. Rev. Phytopathol. 31:81-109.

6. Henson, J. M., Goins, T., Grey, W., Mathre, D. E., and Elliot, M. L. 1993. Use of polymerase chain reaction to detect Gaeumannomyces graminis DNA in plants grown in artificially and naturally infested soil. Phytopathology 83:283-287.

7. Innis, M. A., and Gelfand, D. H. 1990. Optimization of PCRs. In: PCR Protocols: A

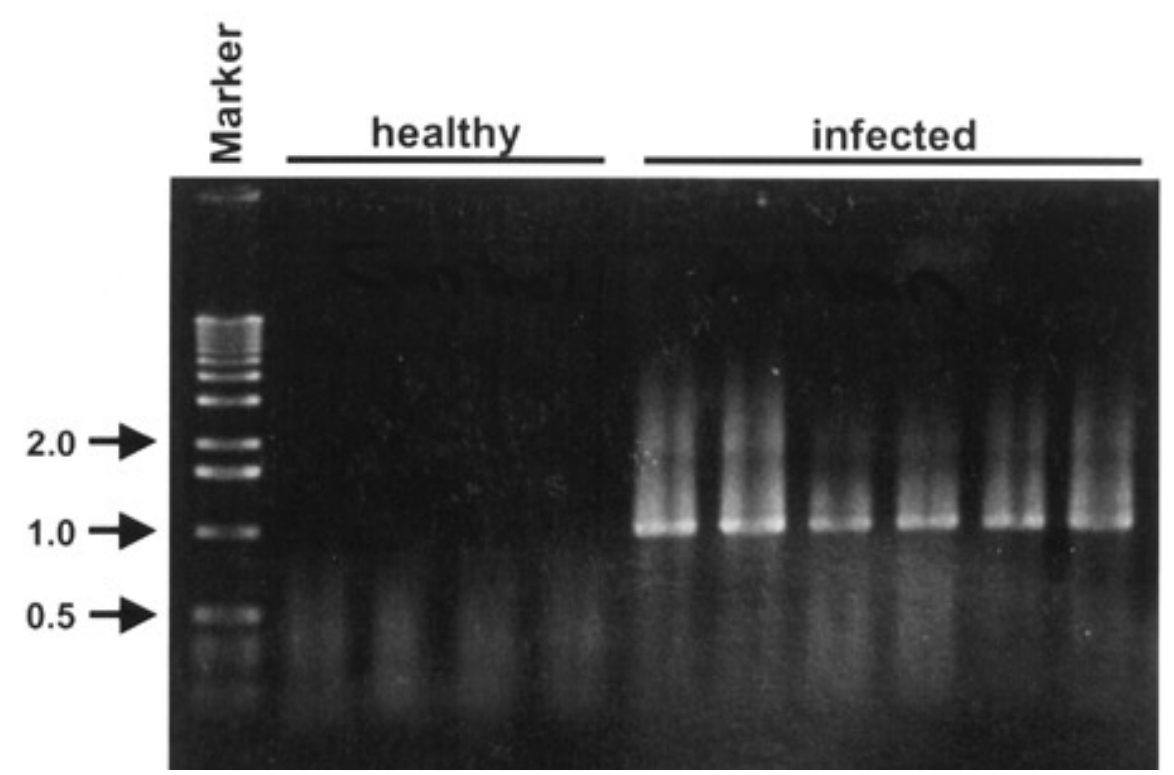

Fig. 6. Detection of Aphanomyces cochlioides in diseased sugar beet seedlings using polymerase chain reaction (PCR) with primers 5FWDACT and MIDREVACT. Extracts were prepared from healthy and diseased seedlings 7 days post-inoculation. Each sample extract was prepared from 4 to 5 seedlings. Tests for the presence of A. cochlioides based on the amplification of the 0.9-kilobasepair (kbp) actin-gene PCR product were performed in duplicate. The 1-kbp ladder was co-electrophoresed as a size standard (Marker).
Guide to Methods and Applications. Academic Press, San Diego, CA.

8. Kageyama, K., Ohyama, A., and Hyakumachi, M. 1997. Detection of Pythium ultimum using polymerase chain reaction with species-specific primers. Plant Dis. 91:1155-1160.

9. Li, K. N., Rouse, D. I., and German, T. L. 1994. PCR primers that allow intergeneric differentiation of ascomycetes and their application to Verticillium spp. Appl. Environ. Microbiol. 60:4324-4331.

10. Liu, Z. L., and Sinclair, J. B. 1992 Genetic diversity of Rhizoctonia solani anastomosis group 2. Phytopathology 82:778-787.

11. Malvick, D. K., Grau, C. R., and Percich, J. A. 1998. Characterization of Aphanomyces euteiches strains based on pathogenicity tests and random amplified polymorphic DNA analysis. Mycol. Res. 102:465-475.

12. Mazzola, M., Wong, O. T., and Cook, R. J. 1996. Virulence of Rhizoctonia oryzae and $R$ solani AG-8 on wheat and detection of $R$. oryzae in plant tissue by PCR. Phytopathology 86:354-360.

13. McElroy, D., Zhang, W., Cao, J., and Wu, R. 1990. Isolation of an efficient actin promoter for use in rice transformation. Plant Cell 2:163-171.

14. Olsen, G. J., and Woese, C. R. 1993. Ribosomal RNA: a key to phylogeny. FASEB J. 7:113-123.

15. Papavizas, G. C., and Ayers, W. A. 1974 Aphanomyces species and their root diseases in pea and sugarbeet. U. S. Dep. Agric. Res. Serv. Tech. Bull. 1485. Washington, DC.

16. Reece, K. S., McElroy, D., and Wu, R. 1992. Function and evolution of actins. Evol. Biol. 26:1-34.

17. Saghai-Maroof, M. A., Soliman, K. M., Jorgenson, R. A., and Allard, R. W. 1984. Ribosomal spacer-length polymorphisms in barley: Mendelian inheritance, chromosomal location, and population dynamics. Proc. Natl Acad. Sci. USA 81:8014-8018.

18. Schilling, A. G., Moller, E. M., and Geiger, H. H. 1996. Polymerase chain reaction-based assays for species-specific detection of Fusarium culmorum, $F$. graminearum, and $F$. avenaceum. Phytopathology 86:515-522.

19. Singleton, L. L., Mihail, J. D., and Rush, C. M. 1992. Methods for Research on Soilborne Phytopathogenic Fungi. APS Press, St. Paul, MN.

20. Tooley, P. W., Bunyard, B. A., and Carras, M M. 1997. Development of PCR primers from internal transcribed spacer region 2 for detection of Phytophthora species infecting potatoes. Appl. Environ. Microbiol. 63:1467-1475

21. Trout, C. L., Ristaino, J. B., and Madritch, M. 1997. Rapid detection of Phytophthora infestans in late blight-infected potato and tomato using PCR. Plant Dis. 81:1042-1048.

22. Ward, E., Adams, M. J., Mutasa, E. S., Collier, C. R., and Asher, M. J. C. 1994. Characterization of Polymyxa species by restriction analysis of PCR-amplified ribosomal DNA. Plant Pathol. 43:872-877.

23. Weiland, J. J. 1997. Rapid DNA preparation from fungal spores and mycelia. Fungal Genet. Newsl. 44:60-63.

24. White, T. J., Bruns, T., Lee, S., and Taylor, J. 1990. Amplification and direct sequencing of fungal ribosomal RNA genes for phylogenetics. In: PCR Protocols: A Guide to Methods and Applications. M. A. Innis, D. H. Gelfand, J. J. Sninsky, and T. J. White, eds. Academic Press, San Diego, CA.

25. Whitney, E. D., and Duffus, J. E. 1986. Compendium of Beet Diseases and Insects. APS Press, St. Paul, MN.

26. Windels, C. E., Lamey, H. A., Hilde, D., Widner, J., and Knudsen, T. 1998. A Cercospora leaf spot model for sugarbeet: In practice by the industry. Plant Dis. 82:716-726. 